\title{
Categorizing Patterns and Processes in Retail Grocery Internationalisation
}

Steve Burt*, Keri Davies, John Dawson and Leigh Sparks

*Corresponding author

Institute for Retail Studies

Department of Marketing

University of Stirling

Stirling, FK9 4LA

June 2006

UK

REVISED January 2007

Email: s.l.burt@stir.ac.uk 


\title{
Categorizing Patterns and Processes in Retail Grocery Internationalisation
}

\begin{abstract}
$\underline{\text { Abstract }}$
The last two decades have been characterised by an increasing internationalisation of retail activity and a considerable number of academic attempts to classify or categorise this activity. A number of different classifications have been proposed based mainly on interactions amongst geographical spread, market entry, managerial outlook and managerial flexibility. However, an examination of three leading international grocery chains on such criteria reveals little communality in pattern or process. Instead internationalisation is marked by different, perhaps serendipitous, patterns and by periods of retrenchment and reconsideration of activities, within a generic strategy of front of store adaptation and back of store standardisation. Previous classifications are therefore partial, time-bound semi-descriptions which need to be supplemented by detailed long-term examination of the internationalisation activities and processes of individual companies.
\end{abstract}

Keywords: Retail, Internationalisation, Globalisation, Classification, Grocery. 


\section{Categorizing Patterns and Processes in Retail Grocery Internationalisation}

\section{Introduction}

In the search for explanation we inevitably simplify. The outcome of complex processes are codified and categorised into classifications and typologies as we seek order and explanation. Despite arguments that retailing has particular characteristics that distinguish it from many other industrial sectors, there is a tendency to draw upon established concepts and frameworks derived in other circumstances to provide convenient labels and typologies which simplify our descriptions of a complex retail phenomenon.

The growing focus on retailing as a process rather than an activity, and upon the organisation and management of value chain activities as a framework for understanding retail internationalisation is no different. At a macro level, the value chain approach emphasises differences in retail contexts which influence how activities and behaviours are shaped throughout the value chain. In the search for order and simplification we may, however, ignore significant variations in behaviour and outcomes. This paper seeks to explore the extent to which a common strategy for internationalisation can be found within the context of one retail value chain.

We start by exploring the broad themes of geographical expansion and operational process which are found within existing attempts to categorise retail

internationalisation. These themes are then considered within the retail grocery sector through the cases of three European based grocery retailers, who would appear to be the most international or "global" in terms of the scope of their activities. Finally, from the experiences of these three companies we assess whether our current categorisations and understanding of patterns and processes of retail grocery internationalisation are adequate.

\section{Patterns and Processes in Retail Internationalisation}

There have been numerous attempts to classify retail internationalisation. The terminology used is, however, inconsistent and at times contradictory (Helferich et al 
1997). Despite this, within the various frameworks proposed over the last two decades of research, two themes consistently emerge. First, the geographical spread of markets, related to the number of countries entered and the concepts of geographical and cultural distance. Secondly, the degree of responsiveness or adaptation to local market conditions, whether at the level of the firm, format or brand. These considerations have structured much of the study of retail internationalisation and attempts to codify patterns and processes.

\section{Geographical Spread: direction and sequence}

The geographical dimension of retail internationalisation is a common theme in the academic literature, typified by studies measuring who went where, when, and how. Studies have charted specific geographical flows (eg Kacker, 1985; Hamill and Crosbie, 1990; and Muniz-Martinez, 1998), or the activities of individual companies (eg Wrigley 1997a; 1997b; 2000; Laulajainen 1991a, 1991b). Geographical spread is typically measured by the number of markets in which a retailer operates. Attempts to explain these geographical patterns have led to explorations of related issues such as: the motives for internationalisation (e.g. Williams, 1991; Alexander 1990, 1995, Quinn 1999, and Vida 2000); the role and choice of entry mechanism (Burt 1991, 1995; Quinn 1998; Doherty 2000); and most recently patterns and explanations for divestment (Alexander and Quinn, 2002; Burt, Dawson and Sparks, 2003; 2004; Alexander, Quinn and Cairns, 2005).

Research into the patterns of retail internationalisation has suggested that companies move first into geographically or culturally close markets. As familiarity with international markets and the operational issues involved increases over time, they then move further afield into more culturally, often geographically, distant markets. This spreading pattern, based on the concept of psychic distance, mirrors the stages approach to internationalisation in the international and export marketing literature.

In a retail context, Treadgold (1990) proposed a three stage model of expansion in geographical presence over time. Retailers passed through stages of reluctance, caution and ambition, as they became more pro-active in their response to international market opportunities and experience curve effects influenced managerial 
perceptions of risk. A link to the Uppsala school is also explicit in the work of Vida and Fairhurst (1998), who suggest that the decision to enter a market will be determined by a company’s capacities (firm characteristics) and management perceptions (decision maker characteristics). As experience grows, retailers overcome these inhibitors and become more ambitious in their strategic outlook.

Although intuitively appealing, the concept of psychic distance is loosely defined and often lacks empirical support. Evans and Mavondo (2002) differentiate between distance and uncertainty, and suggest evidence of a psychic distance paradox, whereby performance is enhanced in more "distant” countries. This builds on the observations of O’Grady and Lane $(1996,1997)$ who found that in the case of Canadian retailers operating in the USA, cultural "closeness" did not guarantee success. Despite this evidence base the concept of staged expansion related to cultural proximity is still widely advocated.

\section{Market Entry: managing risk and control}

Broad strategic issues such as entry method, with its implications for cost and control, have also been integrated into existing frameworks. The choice of entry method is viewed as one way of minimising risk and overcoming perceptions of cultural distance. Treadgold (1988) used geographical presence (defined as concentrated, dispersed, multinational and global), and entry and operating strategy, (represented by levels of cost and control), to identify four types of international retailer: the cautious internationalists, who use high cost entry mechanisms (internal growth or acquisition) to expand in one or two markets; the emboldened internationalists, also with high cost entry mechanisms but operating in a wider spread of markets; the aggressive internationalists, who have high cost entry methods over a very wide spread of markets; and the world powers, characterised by low cost entry mechanisms (franchising) and a large international presence.

In their study on the European retail grocery sector, Gielens and Dekimpe (2001) consider the impact of five entry decision dimensions on performance. They suggest that higher performance and efficiencies arise from early entry, with substantial scale, without partners or acquired assets, offering a format new to the market but familiar 
to the company. This study again emphasises the significance of strategic business decisions and managerial approaches in what can often be seen as simply a process of market led geographical dispersion.

\section{Managerial Outlook: corporate culture and management approach}

Other typologies combine geographical spread with managerial outlook, and in particular the cultural orientation of the business. For example, Helferich et al (1997) use four criteria: geographical spread; a cultural dimension, encompassing both presence in different cultural zones (as opposed to number of markets) and cultural business orientation (ethnocentric, polycentric, mixed and geocentric); a marketing perspective, seen as the degree of standardisation or local market adaptation; and a management perspective, defined as the locus of operational control. On this basis they distinguish between international retailers, beginners or slow developers whose aspirations are limited to one or two culturally similar neighbouring markets; global retailers, fast developers or inimitable niche retailers who have expanded beyond their own cultural zone and/or continent; transnational retailers, viewed as accumulators of experience who develop at a more steady pace with an emphasis on decentralisation or customisation; and multinational retailers who are portfolio managers operating separate units in a wide range of geographically cultural environments.

Similarly, Alexander and Myers (2000) combined market and corporate dimensions through the constructs of market extension (high or low degrees of market coverage) and corporate perspectives (the degree of ethnocentricity or geocentricity). The latter dimension incorporates considerations of control mechanisms, market responsiveness, corporate values and international responsiveness. Their classification defines retailers as proximal, multinational, transnational and global. Both proximal and multinational retailers retain an ethnocentric perspective to internationalisation, whilst the transnational and global companies develop the managerial competences which facilitate internationalisation. Owing to its geocentric mindset, the global retailer may adapt their operations to suit the local market.

The management perspective - the way in which the company organises and projects itself is also evident in the two "competing" corporate models of "globalized retail 
operations” identified by Wrigley (2002): the intelligently federal umbrella organization model, which is characterised by partnerships and alliances, skill and knowledge transfer, format adaptation, and systems integration; and the aggressively industrial category killer model characterised by centralised bureaucracy, exported corporate cultures, and limited format adaptation.

\section{Managerial Flexibility: replication and adaptation}

The above classifications combine some measure of geographical spread with management perceptions of how to respond to international risk. Inherent in these approaches is a consideration of market responsiveness and operational flexibility, whether directly through a prescribed approach to operational activities or inherent in an underlying behavioural approach to international markets.

Salmon and Tordjman (1989) identify three strategies for retail internationalisation at the level of the firm. The first of these is a purely financial investment in a foreign operation which entails little day-to-day involvement. The global strategy requires a high level of standardisation in marketing and operational activities. Economies of scale and replication are sought, and a distinctive product range or brand, backed by a high degree of central control and vertical integration within the value chain, is a common feature. The alternative, a multinational strategy, requires a multi-domestic approach in which marketing activities and operational decisions are made on a country by country basis, tailored to local market and competitive conditions.

At the format level, Goldman (2001) suggests six transfer strategies when entering a developing market. Again these options revolve around the degree of managerial flexibility or adaptation of a core retail concept. Whilst the global niche and opportunism options dove-tail with the traditional global or multinational views, Goldman suggests other options which are variations on a theme. The format pioneering opportunity strategy, involves the development of a "regional" format which is replicated within a specific part of the world; the format extension compatible country of origin strategy, applies to the transfer of a home format with limited changes; and the portfolio based format extension, involves a similar transfer but based on a non-domestic format. Finally the competitive positioning orientated 
strategy entails a maximisation of the key strengths of the format in light of existing indigenous competition.

Finally, others such as McGoldrick (1998), Burt and Carralero-Encinas (2000), and Burt and Mavrommatis (2006) narrow the level of analysis to the standardisation and replication of store and corporate image transfer across national boundaries.

\section{The Product Sector Lens}

The examples used to illustrate the various typologies discussed above tend to categorise grocery retailers as being inclined towards markets with a closer cultural fit and exhibiting more market adapted operational strategies, whilst non-food retailers (particularly in fashion and other "lifestyle" related categories) exemplify a rapid geographical spread to far-flung markets in a largely standardised manner. In short, a "product sector" layer is often transposed on existing frameworks, reflecting differences in the configuration of value chains.

This dimension is further illustrated by research into the internationalisation of the fashion sector (eg Moore 1996, 1997; Fernie et al, 1997; Moore et al, 2000; Doherty, 2000; Picot-Coupey, 2006: Burt et al 2006a). Although primarily focusing on the choice of entry mode and the entry decision, these studies suggest that the specific characteristics of this sector, with a more highly integrated value chain, imply a different process and an evolution in approach as markets are entered and developed. Inherent in this work is the notion of evolution and change over time, a further important consideration in the internationalisation process.

The value chain perspective on retail internationalisation, perhaps most evident in the global versus multinational strategy debate, further emphasises the sector context. The very nature of the grocery market suggests a more localised (and adapted) value chain in terms of consumer orientated market activities, and the structure of the supply chain, although operational processes show increasing signs of coordination and replication across geographical markets. 


\section{Context and Approach}

A criticism that can be levelled at many of the attempts to categorise retail internationalisation is the broad and somewhat selective approach to the evidence base. Internationalisation in most retail firms is complex and dynamic and so support for any framework can be gained by selecting an event within the complex process of the firm. It is possible in the literature to see the same firms being used to provide support for competing interpretive frameworks, because specific events at different times in the internationalisation process of the firm have been selected.

This paper takes a different starting point for its analysis. It begins from the "ground" up. To do this, three retailers with a long history of involvement in retail internationalisation are examined. For each company secondary records obtained via Annual Reports and the trade press are used to build up a picture of their international activities and approaches over the past four decades. By looking at the patterns and processes in practice over an extended period, it is anticipated that more can be said about our categorizations and classifications, and the dynamics involved. It is, however, accepted that this focus is in itself selective and should be replicated in other sectors and with other cases.

The grocery sector is chosen for its scale and significance in internationalisation. However, the nature of grocery retailing raises several contradictions in terms of retail internationalisation and the attempts to categorise international retailers. What is essentially a culture bound product market, with national and regional differences in diet, taste, and attitudes to food preparation translated into consumption and shopping behaviour is increasingly served by large non-domestic organisations, seeking international economies of scale, scope and replication. The tension between serving the needs of local customers whilst leveraging organisational scale is evident and poses specific issues for the value chain. Can grocery markets in different countries be served by a firm using a common retail strategy? Is there a "preferred” business model for grocery internationalisation? What are the generic aspects, if any, of grocery retailing and what aspects are specific to consumer cultures? 
For several years, $\mathrm{M}+\mathrm{M}$ Planet Retail have produced listings of the major grocery based retailers by total sales. Just as the total sales ranking (Table 1) reflects the size of the domestic American and the larger European markets, when one considers internationalisation by the proportion of total sales which are made outside the home country a different array of retailers emerge. Given the size of the domestic market it is not surprising that the American chains achieve a relatively lower proportion of total sales from non-domestic markets than their European counterparts. This exercise also emphasises some retailers from smaller European markets (eg Belgium and the Netherlands), where one could argue that internationalisation is inevitable to maintain sales growth. Furthermore, the European based organisations in this table, with the exception of Delhaize, also operate in at least a dozen markets, illustrating a significant international spread of operations, which as discussed earlier is an important criterion in categorisations of international retailers. From these perspectives one could argue that the "true" leaders of retail internationalisation are the European based chains,

[Table 1 here]

Data from Retail Forward for the previous year allow the origin of sales to be combined with the number of countries within which organisations operate, creating a visual representation of international 'reach' (Figure 1). In terms of the proportion of sales achieved from non-domestic markets and the spread of markets, four broad groupings can be identified. The first contains those organisations achieving under $20 \%$ of sales from a handful (typically 5-7) markets; the second group encompassing Auchan, Aldi, Tesco and Wal-Mart, achieve a higher proportion of sales (20-40\%) from a wider range of markets (10-15); The third group represents further international commitment either through more markets (Ito-Yokado and Casino) and/or a greater proportion of non-domestic sales (Tengelmann and Schwarz); finally the “outliers” comprise of Carrefour and Metro with substantial sales (circa 50\%) from a wide range of markets (circa 30), and Delhaize and Ahold with dominant international sales (circa 80\%) from fewer markets $(<20)$.

[Figure 1 here] 
We will now consider three of the most international grocery retailers as illustrated by Figure 1: Ahold of the Netherlands; Carrefour of France; and the Delhaize Group of Belgium. Despite its "position” Metro is not considered in this analysis because of the high proportion $(50 \%+)$ of non-food sales. The scale and scope of the international operations of these three companies over the past fifteen years is presented in Table 2. This table instantly highlights differences between the companies in terms of the size and spread of the store portfolio. The subsequent discussion will be structured to follow the themes identified in our earlier review of existing attempts to classify retail internationalisation.

\section{Discussion}

\section{Corporate Goals, Objectives and Intent}

What do the activities and public pronouncements of these three experienced international grocery retailers show us? Table 3 considers the stated goal or ambition and intent of the respective groups at mid 2006. Typically the broad vision statements encompass a mixture of stakeholder perspectives and are often framed in terms of how others perceive them. Carrefour and Delhaize phrase their ambition within a performance-benchmarking type perspective, namely to be the "point of reference for modern retailing" (Carrefour) and "to be one of the most admired international food retailers" (Delhaize). A similar emphasis was found in Ahold in the late 1990s :"to be the best and most successful food provider in the world" but has given way to "we make life easy for our customers to choose the best - for themselves and the people they care about" .

[Table 3 here]

As one might expect from major companies in the retail sector all three comment on the need to reflect local customer needs in their operations. They state that formats and channels need to be based on customer needs in individual markets, whilst the identification of core competencies reflect a combination of format and store innovation with operational efficiency and excellence. All support their broad vision with statements acknowledging the importance of scale at the local level within host markets. Delhaize refers to itself as an international group of local companies, and 
aims for its various businesses to be amongst the leading three chains in their respective regions. This view is echoed in Ahold's recent Retail Review (November 2006) which states the aim of becoming "market leaders in local food markets", defined as the number one or two position in that market. In Carrefour's case scale is articulated as "powerful” networks, and the role of complimentarity amongst its trading formats is also regularly voiced.

The need to react to and adapt to local customers and local market trading conditions, plus the importance of establishing scale at the national market level reflects the characteristics of the grocery market value chain, and has been recognised in the literature. Such a stance should, logically, have implications for the choice of markets, scope of investment and decisions about divestment, and the approaches taken to operating in international markets.

\section{Geographical Presence: spread, scope and entry method}

The first common theme in the academic literature is the geographical pattern of internationalisation, encompassing both the geographical spread and scope of investment and the market entry mechanisms employed (Table 4). As far as the geographical pattern of investment is concerned, all three companies have at one time operated on at least three continents, although expansion patterns exhibit marked differences, and in all cases some degree of retrenchment and country exit has occurred.

i) expansion

There is little evidence of a clear pattern (or indeed commonality) in respect to either geographical or cultural proximity. Carrefour was the first to move into non-domestic markets in 1969, with joint ventures into Belgium and Italy. During the mid 1970s, first Delhaize and then Ahold invested in the North American market, one which Carrefour initially ignored (and then failed in at the end of the 1980s), in preference for the "core” European and Latin American markets. While one might possibly claim some cultural "proximity" for the Dutch and Belgian moves into to the USA, an 
overview of the first five or six markets entered, before the "rush" of the mid 1990s shows a widely dispersed pattern (Table 5).

[Table 4 here]

Although Ahold is often regarded as being a long-established international player, prior to the 1990s investment was confined to the group's first attempt to establish itself in Spain between 1976 and 1985, and consolidation in the US with the initial acquisition of Bi-Lo in 1977, followed by Giant Food Stores (1981), First National Supermarkets (1988) and Tops (1993). Ahold's pattern of entry into Spain through the formation of CadaDia in 1976; the acquisitions in the USA from 1977; greenfield entry into Czechoslovakia in 1991; the replacement of Delhaize in an existing joint venture in Portugal in 1992; and entry into Poland in 1995 via a joint venture with a German company (Allkauf), implies more support for the market opportunity (market pull) thesis than a pre-planned strategy based on geographical or cultural proximity. A noted omission from Ahold's movements, until the ICA joint venture of 1999, is any significant investment in the "core” European markets. Prior to this, Ahold's European presence had entailed the Czechoslovakian, Portuguese and Polish ventures noted above, plus a return to Spain in 1996. In all of these markets (with the exception of Portugal), Ahold was required to build up chains from a very low base, rather than investing in existing chains, its common pattern elsewhere.

A diffused geographical pattern also characterises Delhaize's early moves into foreign markets. The 1974 acquisition of a stake in Food Town Stores (later renamed Food Lion) in the USA, was followed by entry into Germany (1977-79), Portugal (198192), Czechoslovakia (1991) and Greece (1992). Finally, while the early moves of Carrefour in the 1970s imply some degree of geographical or cultural proximity (Belgium 1969; Italy 1969; Switzerland 1970; UK 1972; Spain 1973; Brazil 1975; Austria 1976; and Germany 1977), this mix of markets of different sizes and competitive situations, and the subsequent retrenchment within Europe in the late 1970s and early 1980s, suggests that market opportunity for the "new" hypermarket innovation in "less mature" markets is an equally valid explanation for market choice. The opportunism thesis and random walk argument (Dawson 2001) may provide a 
better foundation for explaining these initial patterns of investment, rather than attempts to link or 'force' patterns to fit the geographical or cultural proximity thesis.

[Table 5 here]

The geographical pattern exhibited by Carrefour is particularly opaque if one is searching for the linkages expected from the literature. Following withdrawal from a number of European markets in the early 1980s, the end of that decade saw ventures into the USA (1988) and Taiwan (1989). It was during the 1990's however that Carrefour really expanded to all corners of the globe, including some of those European markets that it had previously abandoned (e.g. Italy, Belgium and Switzerland). The company's thirtieth anniversary in 1993 saw a "sea change” in international strategy. Countries were defined as “core mature markets” (France and Spain), where the future emphasis would be on raising competitiveness; "growth opportunity markets” (Brazil, Argentina, Portugal and Taiwan), where scope existed for further expansion of established businesses; and “new markets” (Italy, Malaysia, Turkey), where entry was at its initial stages. This strategy realignment led to the closure of the American operation, and a major Asian expansion to supplement the existing Taiwanese business, with entry into Malaysia, China, Hong Kong, Thailand, South Korea, Singapore, Indonesia, and Japan between 1994 and 2000. In Latin America, the established Brazilian and Argentinian presence was complemented by entry into Mexico (1994), plus Chile and Columbia (1998), whilst in Europe between 1997 and 2001 new markets included Poland, the Czech Republic, Slovakia, Romania and a return to Switzerland, whilst the Promodès merger in 1999 consolidated its presence in many existing markets.

From observation of the timing and destination of these international moves, one could argue that changes in political or market circumstances, making specific countries attractive or accessible at specific time periods, were key determinants of the patterns exhibited by these three companies. The common denominator in the geographical pattern of expansion is the universal rush to Asia in the mid 1990s. The liberalisation of foreign ownership and general “opening up” of many markets in this part of the world, with favourable demographics and growing economies, and which would be generally perceived as underdeveloped in modern retailing terms, may be 
the most plausible explanation for this investment. It is also possible to argue for "herding" in which firms copy the activities of others in a view that risk, in the intrinsically high risk strategy of international market entry, has been evaluated by others to be acceptable. The short term Asian economic crisis at this time also made investments affordable and available (Davies 2000). Likewise politico-economic changes underpin moves into Central Europe, and Ahold's rapid expansion into, and Carrefour's market consolidation in Latin America in the late 1990s. Expediency and change at the level of the firm is also evident in the case of investments in companies with existing international operations, as in the case of Ahold in Latin America and Scandinavia, and Carrefour's acquisitions of “domestic” companies - Euromarché (1991), Comptoirs Modernes (1998) and most significantly Promodès (1999) - all of which added international store networks and potentially changed the "direction” of international strategy. The Promodès merger also introduced the enlarged group to franchising - a method which has most recently been employed to enter a number of Middle Eastern markets

ii) retrenchment

Table 5 and the discussions above also show a number of withdrawals from markets. As noted earlier, academics have recently identified this as an important dynamic within the retail internationalisation process. All three companies have exited markets at different times and in various circumstances. Additionally, Table 6 does not show other changes in store networks and ownership within countries, for example store disposals in the USA by Ahold and Delhaize. There are examples of exit and return to specific markets: Ahold in Spain; Delhaize in Germany; and Carrefour in Belgium, Italy (twice); Turkey and the UK (although the second venture also failed). In other cases, markets have been exited without return. Although Ahold's financial problems distort the picture, there was clear sign of pressure in the Asian region before its crisis, as Ahold restructured its activities and withdrew from Singapore and China in 1999. Carrefour, like others who attempted to take the hypermarket format into the USA, quickly withdrew from the market (Tordjman, 1988), and also exited from Germany, the UK and Hong Kong. The review of activities instigated by a new management team in 2003-04 has subsequently led to retreat from Chile (2003), hypermarkets in Portugal (2004), from Mexico, Japan, and the Czech and Slovak (all 
2005) and South Korea (2006), markets “where the Group was no longer on a position to maintain its leadership position” (Annual Report, 2005). Finally, the Delhaize departures from Portugal (1992), France (2001) and Singapore (2003) all relate to joint ventures where the partners changed or decided to withdraw, whilst exit from Thailand (2004) Slovakia (2005) and the forthcoming sale of Delvita in the Czech republic (2007), were rationalised in terms of the scale of investment necessary to achieve leading positions in these markets : "The Group concluded that the financial and HR resources required to gain a profitable presence in the Thai market would be more beneficial when invested in other assets." (Annual Report , 2004).

Given the large number of individual markets and both entry and exit activities observed across these three companies, one perhaps surprising outcome of the geographical spread of activities is that there are no markets where all three are in direct competition. Bi-polar competition is, as one might expect, more common, but again a mix of pairings is evident. Ahold and Delhaize "compete” in the USA; Delhaize and Carrefour meet in Belgium, Greece, Romania, and Indonesia, while Ahold and Carrefour now only face each other in Portugal, a market from which Ahold has announced its intention to withdraw. One would not wish to propose a potentially spurious pattern of competitive "avoidance”, but given the importance of achieving scale and leadership in national markets which is increasingly articulated in company statements, such avoidance and the consequent limited level of "head-on" competition would seem to be a likely outcome of corporate strategy.

One consequence of the recent reassessment of market portfolios, is that asset "swops" are in effect now occurring. Internationalising retailers, including those who are relatively new to internationalisation, have the opportunity to acquire sites, stores or chains in countries from other international retailers (rather than local market operators) eg Wal-Mart has expanded in Central and Southern America through the acquisition of parts of the Ahold empire; Tesco and Carrefour have "swopped" stores in South Korea and the Czech and Sloavak Republics - although the latter deal has run into problems with the national competition authority. A consequence of this is that the international spread of these moves, the nature of the assets and the associated relationships in the acquisition process follow a very different pattern to those of 
initial market entry. This is symptomatic of a maturing market for retail assets internationally and has not surprisingly attracted the attention of regulators

iii) entry and expansion methods

All three companies appear, via their choice of entry methods, to appreciate the need (or legal obligation) for a partner in most international markets. Managerial control is usually sought, and this is particularly evident in the case of Carrefour and Delhaize. Carrefour's traditional pattern of investment is one of joint venturing and partnering followed by consolidation (or divestment) as market share and performance grows (or stagnates) (Burt, 1994). The merger with Promodès introduced a wider range of management control mechanisms with franchising and affiliation more prevalent than in the past, and actively pursued in certain markets. It is, however, notable that the “core” hypermarket business remains predominantly a Carrefour controlled activity. Whilst Carrefour now only directly controls $58 \%$ of the circa 12,000 stores trading under the group's various fascias, only 9\% of the hypermarket network is franchised, compared to $93 \%$ of the convenience stores inherited from Promodès. The origins of Promodès as a wholesaler are reflected in the intensity of this small store network and the management control mechanisms employed.

Similarly, Delhaize has either taken a controlling stake or where possible moved from majority joint venture partnerships to majority shareholdings in most of its international markets, whilst adding scale to its American operation through the purchase of Food Giant (1980); Giant Food Markets (1984); Super Discount Markets (1986); Kash n Karry (1996); Food Fair (1996); Farmer Jack (1999); Hannaford (2000); Harveys (2003) and Victory Super Markets (2004). The importance of consolidation (Wrigley 2001) within the American market was further underlined in the 1999/2000 period, when Delhaize restructured its American activities into a new subsidiary Delhaize America. This newly consolidated operation was then listed on the NYSE, but Delhaize has since repurchased the stock replacing the NYSE listing with Delhaize Group shares.

The Ahold 1992 Annual Report stated: "both in the mature Western European markets and in other areas, Ahold is looking for expansion opportunities through 
acquisition, participation or co-operation”. Acquisitions in the USA, entailing the purchase of seven chains, three substantial blocks of stores, and the Peapod ecommerce business between 1994 and 2002 (plus an aborted bid in 1999 for Pathmark Stores when the Federal Trade Commission intervened), were matched with mostly joint venture investments elsewhere. Outside the North American market Ahold could, from a review of entry mechanisms, be seen to exhibit "looser" control over its international operations; an observation which rather ironically reflects practices which almost brought the company to its knees in 2003. Rapid geographical expansion outside the USA was achieved via four substantial "multi-entry" joint venture arrangements: with Disco-Ahold International Holdings (providing entry into Argentina, Chile, Peru and Paraguay); CARHCO (Costa Rica and Nicaragua); PiazAhold (El Salvador, Guatemala, Honduras) and ICA-Ahold (Sweden, Norway, Denmark, Estonia, Finland, Latvia, and Lithuania), whilst legal requirements also required joint ventures in some Asian markets entered during the 1990s. Although joint venturing appeared to be a "favoured" Ahold entry mechanism during this period, several of these operations, Poland (1995); Spain (1999); Brazil (2000); Malaysia (2000); Indonesia (2002); Argentina, Chile, Peru and Paraguay (2002), were subsequently taken under full control. The financial crises which broke within Ahold in 2003 related to a combination of accounting irregularities in both the US Foodservice business and Disco, plus the inappropriate financial consolidation of most of the large joint ventures raising fundamental questions over internal control mechanisms and governance (Wrigley and Currah, 2003).

This overview of the geographical patterns arising from internationalisation provides evidence of the disjointed nature of the retail internationalisation process. After a period of rapid expansion into new markets during the 1990s, all three companies now appear to be engaged in a process of review and consolidation of their international activities. A combination of changes in ownership and management, disputes with existing joint venture partners, regional economic crises, and the financial collapse of partners may provide as much an explanation for this pattern of expansion and consolidation as the assumption of clear strategic intent.

\section{Managerial Approach: market autonomy and adaptability}


The second common theme in the literature is the nature of responsiveness or adaptation shown to local market conditions. This theme encompasses the degree of market autonomy and adaptability arising from the management approach employed and is reflected in the operational support, format and brand strategies implemented. The position of the three case companies in respect of these factors is summarised in Table 6.

i) corporate philosophy and approach

In terms of the broad management approach to international activities, all three companies recognise a need for local market responsiveness, with the importance of "local” adaptation regularly articulated in company documentation. For example, in 2001 Delhaize described itself as "a federation of local companies, not a centralized, monolithic structure. Therefore, the focus is on empowerment." (Annual Report, 2001), and the localised nature of its operation is similarly emphasised today: "The group is committed to offering a locally differentiated shopping experience to customers in each of its markets, to deliver superior value and to maintaining high social, environmental and ethical standards” (Annual Report 2005) Individual chains are free to devise their own operating positions based on local market knowledge. Local market responsiveness backed by group synergies is a common theme as also articulated by Ahold : "Our strong retail and foodservice brands ensure we are optimally placed to answer our customers' local needs. At the same time, our brands benefit from group synergies that allow us to operate in a simple responsible and efficient way" (Annual Report 2005). Even within the revised continental structure announced at the end of 2006, the support role is still emphasised : “..to leverage our continental capabilities and scale more effectively in support of our local operations” (Ahold Retail Review, 2006)

\section{[Table 6 here]}

Despite these similar claims, corporate structure as projected through organisational charts suggests differences in approach, with Carrefour exhibiting a business format structure based on the core trading formats (hypermarkets, supermarkets, limited line discounters) within each country in which it operates, whilst Delhaize shows a 
regional management structure supported by central business functions, a model that Ahold originally adopted with the formation of four market "arenas" (two in the USA, plus Albert Heijn and Central Europe) since realigned with the formation of two continental operating units to support "local banners".

ii) operational strategy and organizational learning

The outcome of this managerial approach is essentially a pattern of "front" store adaptation and responsiveness to customer needs. Given the claims that the grocery market is a "culture bound" sector, this is not surprising. Behind the store front, however, central support for core business functions is increasingly common and this generally entails formal networks allowing information dissemination, benchmarking and exchange of best practice as the benefits of organisational learning are formally recognised by retailers (Palmer, 2005; Palmer and Quinn, 2005; Jonsson and Elg, 2006). The Delhaize strap-line of "Local Strength, Group Expertise" epitomises the typical approach. Often this support is coordinated at a regional level.

The development of such "backroom” integration allowing for knowledge transfer has been an ongoing process. In Ahold's case the corporate support system has evolved from the Ahold Networking scheme formed in 1998. This scheme had its origins in project specific synergy groups operating across the five American chains, which saw the exchange of EDLP expertise within the United States, and the transfer of retail brand and space management techniques from the Netherlands. Eventually "Project Complete" oversaw the integration of a range of corporate functions throughout the American chains, although individual store fascias were maintained. During the rapid expansion of the late 1990s, the established retail businesses assumed mentoring roles in the developing markets (Albert Heijn supported business development in China, Central Europe and Spain; Giant in Thailand; Tops in Malaysia and Singapore; BiLo in Indonesia and Stop \& Shop in Brazil) and a series of Ahold Competence Centres were founded. The integration of the Central European operations maintained this trend prior to the formation of the regional "arenas” and the Business Support Office (to facilitate common initiatives) as part of the 2003 Recovery Plan. Synergies in value repositioning, optimisation of the supply chain, new format development and private brand penetration plus group wide initiatives on general merchandise and the 
creation of standardised retail systems were identified as potential benefits of this approach.

Decentralised management is a central tenant of the Carrefour approach, whether at home or overseas. Local national management teams are empowered, and historically individual hypermarket managers have had considerable autonomy over store operation (Burt, 1986; Dupuis, Choi and Larke 2006). Homage to this philosophy is evident in Annual Reports: "Carrefour not only exports its unique retailing expertise to the countries in which it operates, it also strives to adapt to their specific environment at every level” (1994) and "Although Carrefour is world-class in terms of size and the resources it allocates to growth, it has chosen to adapt its concepts to local cultures and consumer habits. In this spirit, it relies on a decentralized organization formed from over 50 operating units. Each one is responsible for developing a format and its product lines in one country. This operating method relies on local initiative, thereby providing the best possible match of store configuration with customer expectations" (2002). Operational implementation remains a local decision, and the group argues that although Carrefour, Champion and Dia are now global brands, close to $90 \%$ of inventory is local or regional allowing for local adaptation. The tradename may be the same in different markets, but the offer varies. Such operational decentralisation remains a consistent element of the company ethos, with each concept responsible for developing a format and product/service mix appropriate to the local market.

As with Ahold and Carrefour, the Delhaize approach has been to support the various national businesses with group expertise and know-how. An electronic financial reporting system allowing cross country benchmarking was introduced in 1999 and other examples of intra-group technology transfer include the implementation of central distribution and labour management software in the Czech Republic; category management in Thailand; and the adoption of the US inventory and margin management system in Belgium during 2005 In 2001 the group was restructured around three geographic regions (United States, Europe and Asia) supported by four group functions (finance, human resources, information technology, and legal affairs). This geographical structure has been accompanied by further "back-room” integration at regional level, for example the formation of European IT and Supply Chain 
departments, and the co-ordination of retail product brand initiatives such as the launch of the "365" budget brand in Europe in 2004, and the development of a computer based food safety training programme by the American chains.

iii) format and formulae development

At the store level, while all three are becoming multi-format operations, core formats can be clearly identified. Delhaize's business is built upon the supermarket format: "Delhaize Group goes to the market with a variety of locally adapted store formats, of which the most common is the supermarket" (Annual Report, 2002). In the US, Cub Foods (a large supermarket/superstore hybrid) was sold in 2001, and a major initiative over the past two years has been the "renewal” programme involving segmentation of the supermarket format to include new formulae such as Sweetbay, Bloom and Bottom Dollar, each targeted at specific consumer segments. Similarly in Europe following the successful development of a convenience store format in Belgium, the format was adopted in Greece, Germany, the Czech Republic and (before divestment) Singapore. There is no evidence that Delhaize will move into the hypermarket format.

Carrefour similarly, has historically seen most of its internationalisation strategy firmly rooted in a single format, the hypermarket. Although investment in Comptoirs Modernes had seen the start of an embryonic supermarket business in Spain and Brazil, the Promodès merger was on a totally different scale and marked a clear shift into a multi-format internationalisation strategy. In addition to the supermarket, the merger brought the limited line discount format into the group, despite Carrefour's own failed attempts to internationalise Ed in both the UK and Italy. Whether by strategic choice or expediency Carrefour now makes clear claims of format segmentation and of the scope to infill formats in international markets. All three formats are currently found in France, Spain, Turkey, Greece, Argentina and Brazil. A hypermarket, supermarket and convenience store combination is found in Italy and Belgium, with a hypermarket and limited line discount format combination in China and a hypermarket and supermarket offer in Poland. In Asia, with the exception of China an essentially mono-format (hypermarket) approach exists. The multi-format approach is based on leveraging synergies from the hypermarket operation. 
Hypermarkets establish the logistics and supply platform which then allows the development of smaller store formats.

Finally, Ahold, like Delhaize, traditionally based its business on the supermarket. However, the rapid expansion of the group in the late 1990s transformed it into a multi-format operation with hypermarkets, superstores, convenience stores, discount stores and cash and carries in several of the markets in which it operated. In the rush for floorspace which characterised Ahold's moves in Latin America and Spain, the coherence of the format portfolio which evolved was not clear (Burt, Dawson and Larke 2006b). This situation was addressed by the new management team put in place following the financial irregularities, who acknowledged that this approach had contributed to a lack of focus and structure: "we have been trying to be everything to everybody" (www.Ahold.com (2003)). A period of retrenchment and realignment in formats, markets, processes and infrastructure followed resulting in recognition that the core strength of the business is "supermarkets based on quality".

The clarity of approach (or otherwise) taken to format strategy, is to some extent observed in corporate branding strategies. As stated earlier, all three claim a managerial approach reflecting local market cultures and traditions, but the degree to which this is exhibited in store format branding varies. Ahold has staunchly maintained a plethora of store formulas, often operating multiple fascias in the one market (e.g. Brazil and the USA). Only in Asia was a single fascia, Tops, developed for supermarkets, while in Central Europe the hypermarkets adopted the Hypernova name. The rationale for this multi-fascia approach was a belief that the local tradenames possessed an existing consumer franchise which should be maintained, while Ahold brought "behind-the-scenes" expertise to bear. Delhaize has also tended to maintain the original store tradename and the launch of new formulas as part of the "renewal" programme in the US suggests that the localised approach remains fundamental to group strategy. In Europe the same approach has generally been taken but has often involved the incorporation of the Delhaize "lion” logo, particularly when building businesses from a low base.

Carrefour, although maintaining five additional supermarket brands (Norte in Argentina; GS in Italy; GB in Belgium; Globi in Poland and Gima in Turkey); and 
two additional discount store brands (Ed in France; Minpreco in Portugal), has pursued a greater degree of consolidation of store brand names at the format level, with a clear focus on Carrefour, Champion and Dia. This has on occasion required major rebranding exercises for the hypermarkets (e.g. the conversion of Pryca and Continente in Spain, and GB in Belgium, to Carrefour). As of 2006, the future of the Champion brand in Spain and Brazil is under review given store closures and conversion of others to a new Carrefour Express tradename and a larger Maxi-Dia format. For the largely franchised convenience store network an array of inherited tradenames exist.

The strategies pursued by all three reflect a combination of corporate perceptions and desires, plus the historical constitution of the group. Where (typically) supermarket chains have been acquired or invested in (e.g. Ahold, and to a lesser extent Delhaize), the existing (and known) tradename is retained. When a business has typically been grown organically there has been a greater tendency to introduce a common brand at the company, format or regional level.

\section{Conclusion: common themes, different processes?}

So where does this analysis leave us? It is difficult from this review of three leading international grocery retailers to identify a single retail strategy for international grocery markets or a "preferred” model or approach to grocery internationalisation. The scope to develop and manage a truly "global” grocery chain, within the interpretations we normally place on this phrase, seems limited.

On the evidence from these three cases we can identify common themes of generic strategy, but firm level implementation seems to vary by firm over time. All show a strong commitment to retailing on the international stage and recognise the centrality of a customer focus, which is reflected in mission statements and company pronouncements. However the scope of ambition varies and this may illustrate slightly different, but important perceptions of how these companies view the "globe" and act accordingly. Although all three companies have a long track record of international activity, the pattern of internationalisation varies over both time and space, and the outcome of the internationalisation process in spatial terms is markedly 
different. Events rather than well-implemented pre-planned strategies may determine the spatial patterns we use as a basis for categorisation. Since 2002 there are signs of a consolidation process underway, with focus upon "strong” markets and a rigorous review of activities in "weaker" markets leading to divestment in several instances.

All three companies recognise the need for local market responsiveness (adaptation), and again this is clearly articulated in corporate statements. This operational flexibility to gain cost economies of scope, is sought however via different routes and mechanisms. The locus and degree of managerial autonomy and empowerment varies from the chain to the format to the regional level, and this is reflected in part by differing approaches to branding at format and product level. Increasingly the organisational learning process is formalised, typified by centralised support of the local adaptation of retail operations, via various mechanisms for knowledge transfer, best practice dissemination and cross country benchmarking. Similarly, there is evidence of a multi-format and multi-channel approach to markets, but underlying the internationalisation process in each case are core skills in specific formats which have provided market innovation and driven the internationalisation process, with varying degrees of success.

Retail internationalisation is a process in which management learning is a core activity. The reactions of (and in) host economies are important to the form and function of the business in each market, as are retrenchments and readjustments to market changes (Dawson 2003). There is an inherent assumption in most existing academic interpretations of business outcomes, that strategy is coherent, consistent, and linear, and that the observed patterns in activities are clear and pre-determined. These overviews of three European grocery chains show how contested, punctuated and complex the internationalisation process is. We acknowledge that the examples used here are to some extent "the usual suspects". The choice of other examples Tesco, Auchan, Tengelmann or Rewe, Schwarz and Aldi - we argue would reveal other differences in approach. As academics attempting to explain the internationalisation process we have spent an inordinate amount of time attempting to codify a very complex iterative learning process into simplified models and typologies (usually based on a two by two matrix). In order to make sense of strategic business practices, and the outcomes which we tend to interpret, we need more 
longitudinal and in-depth case histories and studies of many more retailers from different sectors, countries and with different histories. Otherwise the search for order in international retail strategies will remain a distraction, beset by personal and problematic categorizations based on partial evidence. 


\section{REFERENCES}

Alexander, N. (1990), 'Retailers and International Markets: Motives for Expansion', International Marketing Review, 7(4), 75-85.

Alexander, N. (1995), 'UK Retail Expansion in North America and Europe: A Strategic Dilemma’, Journal of Retailing and Consumer Services, 2(2), 75-82.

Alexander, N. and Myers, H. (2000), 'The Retail Internationalisation Process' International Marketing Review, 17(4/5), 334-353.

Alexander, N. and Quinn, B. (2002), 'International Retail Divestment', International Journal of Retail and Distribution Management, 30(2), 112-125.

Alexander, N., Quinn, B. and Cairns, P. (2005). 'International Retail Divestment Activity', International Journal of Retail and Distribution Management, 33(1), 5-22.

Burt, S. (1986). 'The Carrefour Group - the first 25 years', International Journal of Retailing, 1(3), 54-78.

Burt, S. (1991). 'Trends in the Internationalisation of Grocery Retailing: the European Experience', International Review of Retail, Distribution and Consumer Research, 1(4), 487-515.

Burt, S. (1994), 'Carrefour: Internationalising Innovation', in McGoldrick, P. (ed) 'International Retailing: trends and strategies', Pitman: London, 391-410

Burt, S. (1995), 'Retail Internationalisation: Evolution of Theory and Practice', in McGoldrick P (ed) 'International Retailing: trends and strategies', Pitman : London, 51-73.

Burt, S. and Carralero-Encinas, J. (2000), 'The Role of Store Image in Retail Internationalisation', International Marketing Review, 17(4/5), 433-454.

Burt, S., Dawson, J.A., and Larke, R. (2006a), 'Inditex-Zara; re-writing the rules in apparel retailing', in Dawson JA, Larke R and Mukoyama M (eds), 'Strategic Issues in International Retailing', Routledge: London, 71-90.

Burt, S., Dawson, J.A., and Larke, R. (2006b), 'Royal Ahold : multinational, multichannel, multi-format food provider', in Dawson JA, Larke R and Mukoyama M (eds), 'Strategic Issues in International Retailing', Routledge: London,140169

Burt, S., Dawson, J.A., and Sparks, L. (2003), 'Failure in International Markets: research propositions', International Review of Retail Distribution and Consumer Research, 13(4), 355-373.

Burt, S., Dawson, J.A., and Sparks, L. (2004), 'The International Divestment Activities of European Grocery Retailers’, European Management Journal, 22(5),483-492 
Burt, S. and Mavrommatis, A. (2006), 'The International Transfer of Store Brand Image', International Review of Retail Distribution and Consumer Research, 16(4), 395-413

Davies, B.K. (2000), 'The Asian Economic Recession and Retail Change: the implications for retailer strategies in Asia', International Review of Retail Distribution and Consumer Research, 10(4), 335-353.

Dawson, J. (1982), 'A Note on the Law of 29 June 1975 to Control Large Scale Retail Development in Belgium’, Environment and Planning A, 14, 291-6.

Dawson, J. (2001), 'Strategy and Opportunism in European Retail Internationalization’, British Journal of Management, 12, 253-266.

Dawson, J. (2003), 'Towards a Model of the Impacts of Retail Internationalisation' Chapter 11 (p189-209) of Dawson, J., Mukoyama, M., Choi, S.C. and Larke R. (eds) 'The Internationalization of Retailing in Asia'. RoutledgeCurzon: London.

Doherty, A.M. (2000), 'Factors Influencing International Retailers Market Entry Mode Strategy: qualitative evidence from the UK fashion sector', Journal of Marketing Management, 16(1-3), 223-245.

Dupuis, M., Choi, S.C., and Larke, R. (2006), 'Carrefour: being aware of the domestic market!', in Dawson JA, Larke R and Mukoyama M (eds), 'Strategic Issues in International Retailing', Routledge: London, 91-113

Evans, J. and Mavondo, F.T, (2002), 'Psychic Distance and Organizational Performance: an empirical examination of international retailing operations', Journal of International Business Studies, 33(3), 515-532.

Fernie, J., Moore, C., Lawrie, A., and Hallsworth, A. (1997), The Internationalisation of the High Fashion Brand: the case of central London', Journal of Product and Brand Management, 6(3), 151-162

Gielens, K. and Dekimpe, M.G. (2001), 'Do International Entry Decisions of Retail Chains Matter in the Long Run ?', International Journal of Research in Marketing, 18(3), 235-259.

Goldman, A. (2001), 'The Transfer of Retail Formats into Developing Economies: the example of China', Journal of Retailing, 77, 221-241.

Hamill, J. and Crosbie, J. (1990), 'British Retail Acquisition in the US', International Journal of Retail and Distribution Management, 18(5), 15-20.

Helferich, E., Hinfelaar, M. and Kasper, H. (1997), 'Towards a Clear Terminology on International Retailing', International Review of Retail Distribution and Consumer Research, 7(3), 287-307. 
Jonsson, A., and Elg, U. (2006), 'Knowledge and Knowledge Sharing in Retail Internationalisation: IKEA's entry into Russia', International Review of Retail Distribution and Consumer Research, 16(2), 239-256

Kacker, M. (1985), 'Transatlantic Trends in Retailing', Quorum : Westport.

Laulajainen, R. (1991a), 'International Expansion of an Apparel Retailer - Hennes and Mauritz of Sweden’, Zeitschrift für Wirtschaftsgeographie, 35(1), 1-15.

Laulajainen, R. (1991b), ‘Two Retailers Go Global: the geographical dimension', International Review of Retail, Distribution and Consumer Research, 1(5), 607626.

McGoldrick, P. (1998), "Spatial and Temporal Shifts in International Retail Image”, Journal of Business Research, 42, 189-196.

Moore, C.M. (1996), 'La Mode Sans Frontiers? The internationalisation of fashion retailing’, Journal of Fashion Marketing and Management, 1(4), 345-356

Moore, C.M. (1997), 'L’Internationalisation du Pret-a-Porter: the case of Kookai and Morgan's entry into the UK fashion market', Journal of Fashion Marketing and Management, 2(2), 153-158

Moore, C.M., Fernie, J., and Burt, S. (2000), 'Brands Without Boundaries: the internationalisation of the designer retailers' brand', European Journal of Marketing, 34(8), 919-937

Muniz-Martinez, N. (1998), 'The Internationalisation of European Retailers in America : the US Experience', International Journal of Retail and Distribution Management, 26(1), 29-37.

O’Grady, S. and Lane, H. (1996), 'The Psychic Distance Paradox', Journal of International Business Studies, 27(2), 309-333.

O’Grady, S. and Lane, H. (1997), 'Culture: an unnoticed barrier to Canadian retail performance in the USA', Journal of Retailing and Consumer Services, 4, 159170.

Palmer, M. (2005), 'Retail Multinational Learning: A Case Study of Tesco', International Journal of Retail and Distribution Management,.33(1), 23-49.

Palmer, M. and Quinn, B. (2005), ‘An Exploratory Framework for Analysing International Retail Learning', International Review of Retail Distribution and Consumer Research, 15(1), 27-52

Picot-Coupey, K. (2006), 'Determinants of International Retail Operation Mode Choice: towards a conceptual framework based on evidence from French specialised retail chains', International Review of Retail Distribution and Consumer Research, 16(2), 215-237 
Quinn, B. (1998), 'Towards a Framework for the Study of Franchising as an Operating Mode for International Retail Companies', International Review of Retail Distribution and Consumer Research, 8(4), 445-467.

Quinn, B. (1999), 'The Temporal Context of UK Retailers' Motives for International Expansion', Service Industries Journal, 19(2), 102-117.

Retail Forward (2005), 'Top 200 Retailers Worldwide, 2004', Retail Forward Inc, October 2005

Salmon, W. J. and Tordjman, A. (1989), 'The Internationalisation of Retailing', International Journal of Retailing, 4(2), 3-16.

Tordjman, A. (1988), 'The French Hypermarket: Could it be Developed in the States?', Retail and Distribution Management, 16(4), 14-16.

Treadgold, A.D. (1988), 'Retailing Without Frontiers', Retail and Distribution Management, 16(6), 8-12.

Treadgold, A.D. (1990), 'The Emerging Internationalisation of Retailing: Present Status and Future Strategies’, Irish Marketing Review, 5(2), 11-27.

Vida, I. (2000), 'An Empirical Inquiry into International Expansion of US Retailers', International Marketing Review, 17(4/5), 454-475.

Vida, I. and Fairhurst, A. (1998), "International Expansion of Retail Firms: a theoretical approach for future investigations", Journal of Retailing and Consumer Services, 5(3), 143-151.

Williams, D.E. (1991), 'Differential Firm Advantages and Retailer Internationalisation', International Journal of Retail and Distribution Management, 19(4), 3-12.

Wrigley, N. (1997a), 'British Food Retailing Capital in the USA: Part 1: Sainsbury and the Shaw's Experience', International Journal of Retail and Distribution Management, 25(1), 7-21.

Wrigley, N. (1997b), 'British Food Retail Capital in the USA: Part 2: Giant Prospects?', International Journal of Retail and Distribution Management, 25(2-3), 48-58.

Wrigley, N. (2000), 'Strategic Market Behaviour in the Internationalisation of Food Retailing: interpreting the third wave of Sainsbury's diversification', European Journal of Marketing, 34(8), 891-981.

Wrigley, N. (2002), 'The Landscape of Pan-European Food Retail Consolidation', International Journal of Retail and Distribution Management, 30(2), 89-91. 
Wrigley, N. and Currah, A. (2003), 'The Stresses of Retail Internationalisation: Lessons from Royal Ahold's Experience in Latin America', International Review of Retail Distribution and Consumer Research, 13(3), 221-243. 
Table 1: Largest Grocery Based Retailers* in the World - Ranked by Sales, 2005

\begin{tabular}{|l|l|c|c|c|c|}
\hline Group & $\begin{array}{l}\text { Country of } \\
\text { Origin }\end{array}$ & $\begin{array}{c}\text { Retail Banner } \\
\text { Sales } \\
\text { (US\$ mill) }\end{array}$ & $\begin{array}{c}\text { Net Sales } \\
\text { (US\$ } \\
\text { mill) }\end{array}$ & $\begin{array}{c}\% \\
\text { Grocery } \\
\text { Sales }\end{array}$ & $\begin{array}{c}\% \\
\text { Foreign } \\
\text { sales }\end{array}$ \\
\hline Wal-Mart & USA & 338,774 & 312,427 & 44.9 & 22.4 \\
\hline Carrefour & France & 117,175 & 92,597 & 74.1 & 52.4 \\
\hline Metro Group & Germany & 83,237 & 69,260 & 47.4 & 51.7 \\
\hline Tesco & UK & 77,171 & 69,631 & 73.4 & 23.1 \\
\hline Ahold & Netherlands & 76,774 & 55,307 & 84.0 & 82.0 \\
\hline Seven \& I & Japan & 69,237 & 35,324 & 72.0 & 34.0 \\
\hline Kroger & USA & 63,702 & 60,553 & 70.5 & 0.0 \\
\hline Rewe & Germany & 56,527 & 51,832 & 76.4 & 30.5 \\
\hline Costco & USA & 56,456 & 52,935 & 60.2 & 20.5 \\
\hline Casino & France & 53,842 & 28,347 & 74.7 & 41.8 \\
\hline Aeon & Japan & 51,478 & 40,230 & 59.4 & 8.2 \\
\hline Auchan & France & 51,273 & $38,216 \mathrm{e}$ & 62.0 & 47.0 \\
\hline Edeka & Germany & 50,131 & $41,266 \mathrm{e}$ & 85.4 & 6.7 \\
\hline Schwarz Group & Germany & 49,726 & $45,802 \mathrm{e}$ & 82.5 & 43.3 \\
\hline Aldi & Germany & 48,773 & $45,008 \mathrm{e}$ & 83.3 & 44.7 \\
\hline Albertsons & USA & 42,457 & 40,358 & 68.3 & 0.0 \\
\hline Safeway & USA & 42,078 & 38,416 & 75.5 & 16.1 \\
\hline Leclerc & France & 39,539 & 35,424 & 63.0 & 5.6 \\
\hline ITM & France & 36,556 & 37,724 & 66.0 & 10.0 \\
\hline Tengelmann & Germany & 33,024 & $29,986 \mathrm{e}$ & 65.7 & 50.8 \\
\hline Woolworth & Australia & 31,086 & $27,090 \mathrm{e}$ & 70.5 & 8.7 \\
\hline Sainsbury & UK & 30,606 & 30,178 & 76.1 & 0.0 \\
\hline Coles Myer & Australia & 30,150 & 27,853 & 52.0 & 0.6 \\
\hline Loblaw & Canada & 24,994 & 22,943 & 77.4 & 0.0 \\
\hline Delhaize & Belgium & 24,836 & 18,600 & 76.9 & 77.1 \\
\hline
\end{tabular}

* Retailers with $40 \%+$ of sales in Grocery

Source : derived from $\mathrm{M}+\mathrm{M}$ Planet Retail 
Table 2 : International Activities of Ahold, Carrefour and Delhaize Group: 1990, 1995, 2000, 2005

\begin{tabular}{|l|c|c|c|c|c|c|c|c|}
\hline \multirow{2}{*}{ AHOLD } & \multicolumn{4}{|c|}{ Number of Stores* } & \multicolumn{4}{c|}{ Origin of Sales** } \\
\cline { 2 - 10 } & 1990 & 1995 & 2000 & 2005 & 1990 & 1995 & 2000 & 2005 \\
\hline Total & 1210 & 1767 & 4824 & 3455 & 100 & 100 & 100 & 100 \\
\hline North America & 341 & 636 & 1317 & 840 & 47.8 & 51.7 & 68.1 & 61.3 \\
\hline Europe & 869 & 1131 & 3304 & 2615 & 52.2 & 48.3 & 28.1 & 38.7 \\
- Netherlands & 869 & 919 & 2383 & 2113 & 52.2 & 40.9 & 15.6 & 32.8 \\
\hline Latin America & - & - & 106 & - & - & - & 2.4 & - \\
\hline Asia & - & - & 97 & - & - & - & 1.2 & - \\
\hline
\end{tabular}

* consolidated stores only. Unconsolidated stores +2542 (2005)

** origin of sales exclude foodservice sales (retail sales only)

\begin{tabular}{|l|c|c|c|c|c|c|c|c|}
\hline CARREFOUR & \multicolumn{4}{|c|}{ Number of Stores * } & \multicolumn{4}{c|}{ Origin of Sales } \\
\cline { 2 - 10 } & 1990 & 1995 & 2000 & 2005 & 1990 & 1995 & 2000 & 2005 \\
\hline Total & 340 & 968 & 5423 & 7003 & 100 & 100 & 100 & 100 \\
\hline North America & 1 & - & - & - & na & - & - & - \\
\hline Europe & 312 & 898 & 4755 & 5762 & 90.3 & 80.3 & 75.8 & 85.5 \\
- France & 283 & 840 & 1726 & 1664 & 68.8 & 62.0 & 52.5 & 47.8 \\
\hline Latin America & 26 & 57 & 574 & 817 & 9.7 & 17.2 & 14.8 & 6.8 \\
\hline Asia & 1 & 13 & 94 & 424 & na & 2.5 & 6.3 & 7.7 \\
\hline
\end{tabular}

* consolidated stores only. Unconsolidated stores +5025 (2005)

\begin{tabular}{|l|c|c|c|c|c|c|c|c|}
\hline \multirow{2}{*}{ DELHAIZE } & \multicolumn{4}{|c|}{ Number of Stores } & \multicolumn{4}{c|}{ Origin of Sales } \\
\cline { 2 - 10 } & 1990 & 1995 & 2000 & 2005 & 1990 & 1995 & 2000 & 2005 \\
\hline Total & 1195 & 1610 & 2310 & 2636 & 100 & 100 & 100 & 100 \\
\hline North America & 886 & 1086 & 1450 & 1537 & 69.5 & 68.1 & 77.4 & 71.5 \\
\hline Europe & 309 & 524 & 792 & 1053 & 30.5 & 31.9 & 21.7 & 26.4 \\
- Belgium & 278 & 450 & 615 & 808 & 27.3 & 25.8 & 16.4 & 21.5 \\
\hline Latin America & - & - & - & - & - & - & - & - \\
\hline Asia & - & - & 68 & 46 & - & - & 0.9 & 2.1 \\
\hline
\end{tabular}

Source: calculated from Annual Reports 
Table 3 : Corporate Goals, Objectives and Intent

\begin{tabular}{|c|c|c|c|}
\hline & Ahold & Carrefour & Delhaize Group \\
\hline $\begin{array}{l}\text { Business } \\
\text { Scope }\end{array}$ & $\begin{array}{l}\text { "International group of } \\
\text { quality supermarkets and } \\
\text { foodservice operators } \\
\text { based in the United } \\
\text { States and Europe" }\end{array}$ & $\begin{array}{l}\text { "An international multi- } \\
\text { format group" }\end{array}$ & $\begin{array}{l}\text { "A Belgian international } \\
\text { food retailer with } \\
\text { activities in eight } \\
\text { countries on three } \\
\text { continents" }\end{array}$ \\
\hline $\begin{array}{l}\text { Corporate } \\
\text { Goal/Vision/ } \\
\text { Ambition }\end{array}$ & $\begin{array}{l}\text { "we make life easy for } \\
\text { our customers to choose } \\
\text { the best - for themselves } \\
\text { and the people they care } \\
\text { about" }\end{array}$ & $\begin{array}{l}\text { "the point of reference in } \\
\text { modern food retailing" }\end{array}$ & $\begin{array}{l}\text { "to be one of the most } \\
\text { admired international } \\
\text { food retailers by its } \\
\text { customers, its employees } \\
\text { and its shareholders" }\end{array}$ \\
\hline $\begin{array}{l}\text { Intent/ } \\
\text { Approach }\end{array}$ & $\begin{array}{l}\text { “... an easy, convenient } \\
\text { and appealing shopping } \\
\text { experience through } \\
\text { continual customer } \\
\text { focus”; } \\
\text { "we do this through our } \\
\text { strong local brands and } \\
\text { putting the customer at } \\
\text { the heart of every } \\
\text { decision” }\end{array}$ & $\begin{array}{l}\text { "strength in diversity"; } \\
\text { "expansion of powerful } \\
\text { and complimentary } \\
\text { networks that can meet the } \\
\text { needs of local customers } \\
\text { worldwide"; } \\
\text { a multi-format strategy - } \\
\text { "appealing to all types of } \\
\text { customer profiles and of } \\
\text { meeting their full range of } \\
\text { needs"; } \\
\text { "to offer the customer the } \\
\text { greatest freedom of choice } \\
\text { with the guarantee of the } \\
\text { best quality/price ratio, } \\
\text { whatever the store format" }\end{array}$ & $\begin{array}{l}\text { "leading positions in } \\
\text { food retailing in key } \\
\text { markets. These positions } \\
\text { are built through strong } \\
\text { regional companies } \\
\text { going to market in a } \\
\text { variety of food store } \\
\text { formats."; } \\
\text { "the group is committed } \\
\text { to offering a locally } \\
\text { differentiated shopping } \\
\text { experience to customers } \\
\text { in each of its markets, to } \\
\text { deliver superior value } \\
\text { and to maintaining high } \\
\text { social, environmental and } \\
\text { ethical standards" }\end{array}$ \\
\hline $\begin{array}{l}\text { Core } \\
\text { Capabilities/ } \\
\text { Strategic } \\
\text { Levers }\end{array}$ & $\begin{array}{l}\text { Applied customer insight } \\
\text { Superior category } \\
\text { management } \\
\text { Strategic sourcing } \\
\text { End-to-end supply chain } \\
\text { Excellent store } \\
\text { operations }\end{array}$ & $\begin{array}{l}\text { Multi-format growth } \\
\text { - complimentarity and } \\
\text { synergy } \\
\text { Common strategic } \\
\text { positions: } \\
\text { - price leader in catchment } \\
\text { area; } \\
\text { - excel at mastering costs; } \\
\text { - optimal development of } \\
\text { capital employed } \\
\text { - purchasing synergies }\end{array}$ & $\begin{array}{l}\text { Concept leadership } \\
\text { Executional excellence } \\
\text { Learning organization } \\
\text { Attractive workplace } \\
\text { Responsible corporate } \\
\text { citizen }\end{array}$ \\
\hline
\end{tabular}

Source : derived from Annual Reports, Websites and Company Documentation 
Table 4: Geographical Presence: Spread; Scope and Entry Methods

\begin{tabular}{|c|c|c|c|}
\hline & Ahold & Carrefour & Delhaize Group \\
\hline $\begin{array}{l}\text { Geographical } \\
\text { Spread }\end{array}$ & $\begin{array}{l}11 \text { markets on } 3 \\
\text { continents; previously } \\
27 \text { markets on } 4 \\
\text { continents } \\
\text { USA dominant } \\
\text { contributor to sales; } \\
\text { failing in Asia before } \\
\text { financial problems }\end{array}$ & $\begin{array}{l}30 \text { markets on } 3 \text { continents } \\
\text { plus franchise partners in a } \\
\text { further } 9 \text { countries; } \\
\text { failed in USA; } \\
\text { willingness to return to } \\
\text { previously exited markets, } \\
\text { not always successful }\end{array}$ & $\begin{array}{l}\text { now } 5 \text { markets on } 3 \\
\text { continents, in } 20410 \\
\text { markets on } 3 \text { continents; } \\
\text { USA dominant } \\
\text { contributor to sales }\end{array}$ \\
\hline $\begin{array}{l}\text { Geographical } \\
\text { Pattern }\end{array}$ & $\begin{array}{l}\text { USA in mid 1970s and } \\
\text { consolidation since; } \\
\text { entry into Asia/Latin } \\
\text { America in 1990s; } \\
\text { relatively limited } \\
\text { European expansion - } \\
\text { S\&C Europe, and } \\
\text { latterly Scandinavia \& } \\
\text { Baltics; post } 2000 \\
\text { divestment of non-core } \\
\text { markets - retreat from } \\
\text { Asia and Americas and } \\
\text { focus on "core” markets } \\
\text { in USA and Europe }\end{array}$ & $\begin{array}{l}\text { core European markets in } \\
\text { early/mid 1970s; } \\
\text { exit and retrench to "latin" } \\
\text { markets in early 1980s; } \\
\text { spread through Asia and } \\
\text { Europe in 1990s; } \\
\text { Asia, Middle East, Latin } \\
\text { America in late 1990s; } \\
\text { post } 2000 \text { divestment from } \\
\text { markets on all continents } \\
\text { where position is weak }\end{array}$ & $\begin{array}{l}\text { USA in mid 1970s and } \\
\text { consolidation since; } \\
\text { other early moves in 70s- } \\
\text { 80s withdrawn; } \\
\text { during 1990s expanded } \\
\text { to S\&C Europe and Asia } \\
\text { in late 1990s; } \\
\text { retrenchment since } 2003 \\
\text { by divesting smaller } \\
\text { markets were leading } \\
\text { position unatainable }\end{array}$ \\
\hline Entry Method & $\begin{array}{l}\text { acquisition in USA; } \\
\text { JV elsewhere, often } \\
\text { rising to majority (but } \\
\text { forced ?); in past a } \\
\text { number of “multi- } \\
\text { country” entrants via } \\
\text { single JV }\end{array}$ & $\begin{array}{l}\text { initially JV moving to } \\
\text { ownership where } \\
\text { committed; } \\
\text { merger with Promodès } \\
\text { reinforced market presence } \\
\text { and added franchises }\end{array}$ & $\begin{array}{l}\text { management control } \\
\text { either via dominant JV or } \\
\text { majority shareholding }\end{array}$ \\
\hline
\end{tabular}

Source : derived from Annual Reports, Websites and Company Documentation 
Table 5 : Geographical Spread : Country and Year of Entry/Exit

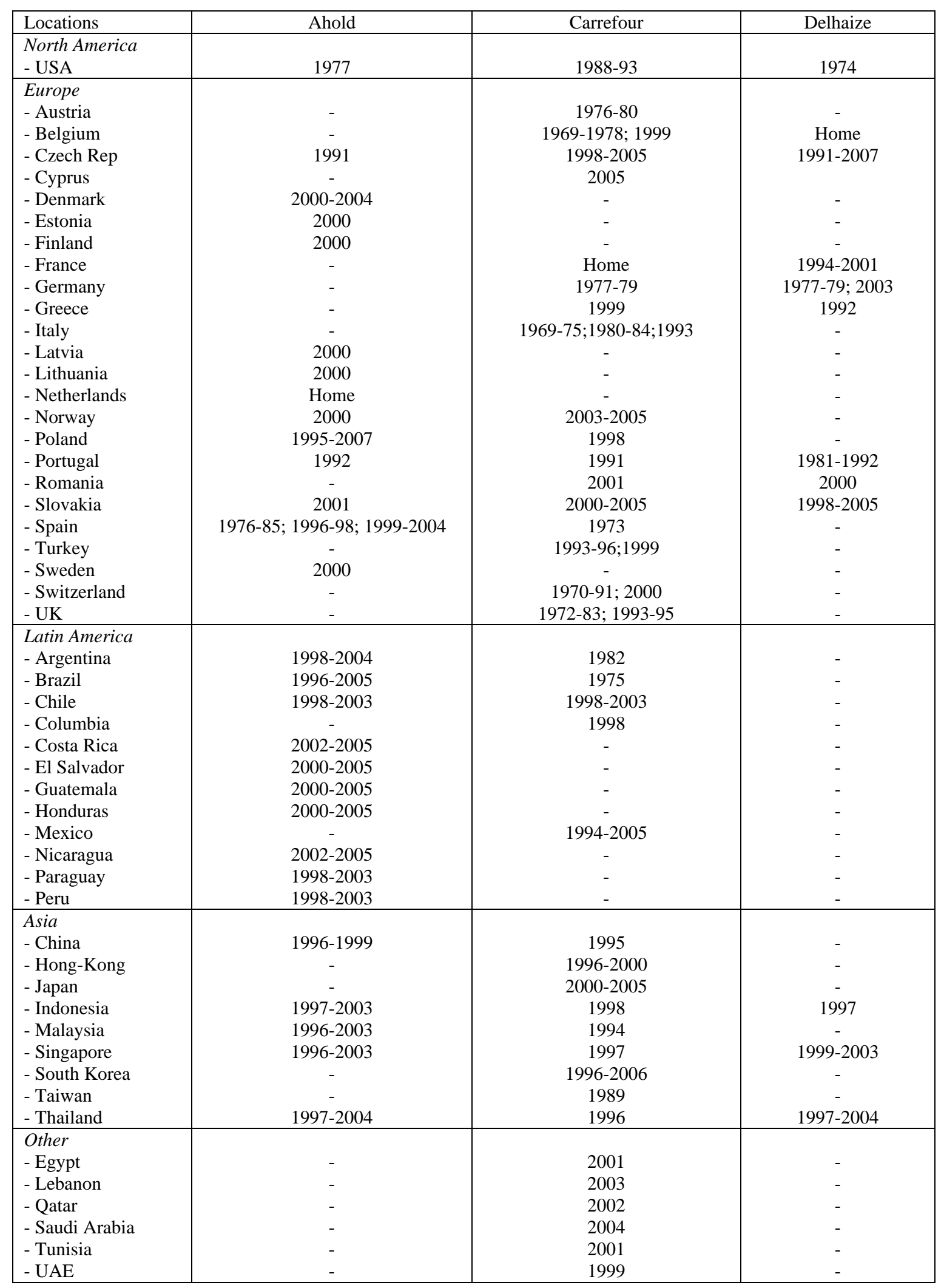

Source: calculated from Annual Reports 
Table 6 : Managerial Approach : Market Autonomy and Adaptability

\begin{tabular}{|c|c|c|c|}
\hline & Ahold & Carrefour & Delhaize Group \\
\hline $\begin{array}{l}\text { Managerial } \\
\text { Approach }\end{array}$ & $\begin{array}{l}\text { "common set of values } \\
\text { and core capabilities } \\
\text { will help us to act as } \\
\text { one company and } \\
\text { capitalise on scale } \\
\text { scope and expertise. At } \\
\text { the same time our } \\
\text { businesses maintain } \\
\text { strong individual } \\
\text { identities to best serve } \\
\text { customers at the local } \\
\text { level” }\end{array}$ & $\begin{array}{l}\text { "an international group, a } \\
\text { local operator"; } \\
\text { autonomy of markets at } \\
\text { operational level; } \\
\text { local player in each market } \\
\text { - "respectful of local } \\
\text { lifestyles and culture"; } \\
\text { "the international } \\
\text { development of various } \\
\text { formats is accompanied by } \\
\text { great flexibility in } \\
\text { adopting to local cultures } \\
\text { and situations" }\end{array}$ & $\begin{array}{l}\text { "international group of } \\
\text { local companies"; } \\
\text { high level of local } \\
\text { management } \\
\text { responsibility "to fully } \\
\text { address their local } \\
\text { consumer needs" and } \\
\text { "motivate local } \\
\text { management"; }\end{array}$ \\
\hline $\begin{array}{l}\text { Managerial } \\
\text { Support } \\
\text { Strategy }\end{array}$ & $\begin{array}{l}\text { Arenas (regional } \\
\text { marketplaces) with } \\
\text { integrated support } \\
\text { service organizations; } \\
\text { standard retail systems; } \\
\text { learning organization to } \\
\text { improve core } \\
\text { capabilities and work as } \\
\text { one team. From } 2007 \\
\text { arena structure } \\
\text { consolidated into two } \\
\text { continental retail } \\
\text { divisions }\end{array}$ & $\begin{array}{l}\text { country structure (within } \\
\text { regions) with each country } \\
\text { controlling and responsible } \\
\text { for operational activities; } \\
\text { within each country a } \\
\text { decentralised business line } \\
\text { (format) structure } \\
\text { operates; } \\
\text { country level functional } \\
\text { support is provided to } \\
\text { formats and networks with } \\
\text { other countries to } \\
\text { exchange best practices } \\
\text { and for specified projects }\end{array}$ & $\begin{array}{l}\text { geographical regional } \\
\text { structure and knowledge } \\
\text { transfer; } \\
\text { central group support in } \\
\text { financial, human } \\
\text { resources, IT and legal } \\
\text { services wich } \\
\text { allows group synergies } \\
\text { and exchange of best } \\
\text { practices }\end{array}$ \\
\hline $\begin{array}{l}\text { Format } \\
\text { Strategy }\end{array}$ & $\begin{array}{l}\text { primarily supermarket, } \\
\text { other formats eg } \\
\text { hypermarket, inherited } \\
\text { from JV or developed } \\
\text { in discrete markets (eg } \\
\text { Central Europe); }\end{array}$ & $\begin{array}{l}\text { initially hypermarket } \\
\text { based with limited } \\
\text { supermarket development; } \\
\text { since Promodès, multi- } \\
\text { format with hypermarket, } \\
\text { supermarket and limited } \\
\text { line discount store as core } \\
\text { formats; neighbourhood } \\
\text { stores in some markets }\end{array}$ & $\begin{array}{l}\text { supermarket format } \\
\text { dominant, no } \\
\text { hypermarkets, some } \\
\text { neighbourhood store and } \\
\text { c-store development in } \\
\text { Europe }\end{array}$ \\
\hline Brand Strategy & $\begin{array}{l}\text { maintain local store } \\
\text { brand name/format } \\
\text { name; retail product } \\
\text { brand expertise } \\
\text { transferred }\end{array}$ & $\begin{array}{l}\text { consolidation of brand } \\
\text { name where possible - } \\
\text { Carrefour, Champion, Dia; } \\
\text { local brand name retained } \\
\text { where significant chain } \\
\text { acquired; } \\
\text { retail product brand range } \\
\text { transferred }\end{array}$ & $\begin{array}{l}\text { local name maintained; } \\
\text { Lion logo incorporated in } \\
\text { some European and } \\
\text { Asian markets; } \\
\text { retail product brand } \\
\text { range transferred eg } \\
\text { “365” budget range in } \\
\text { Europe }\end{array}$ \\
\hline
\end{tabular}

Source : derived from Annual Reports, Websites and Company Documentation 
Figure 1 :

Global Spread of Selected Grocery Retailers, 2004

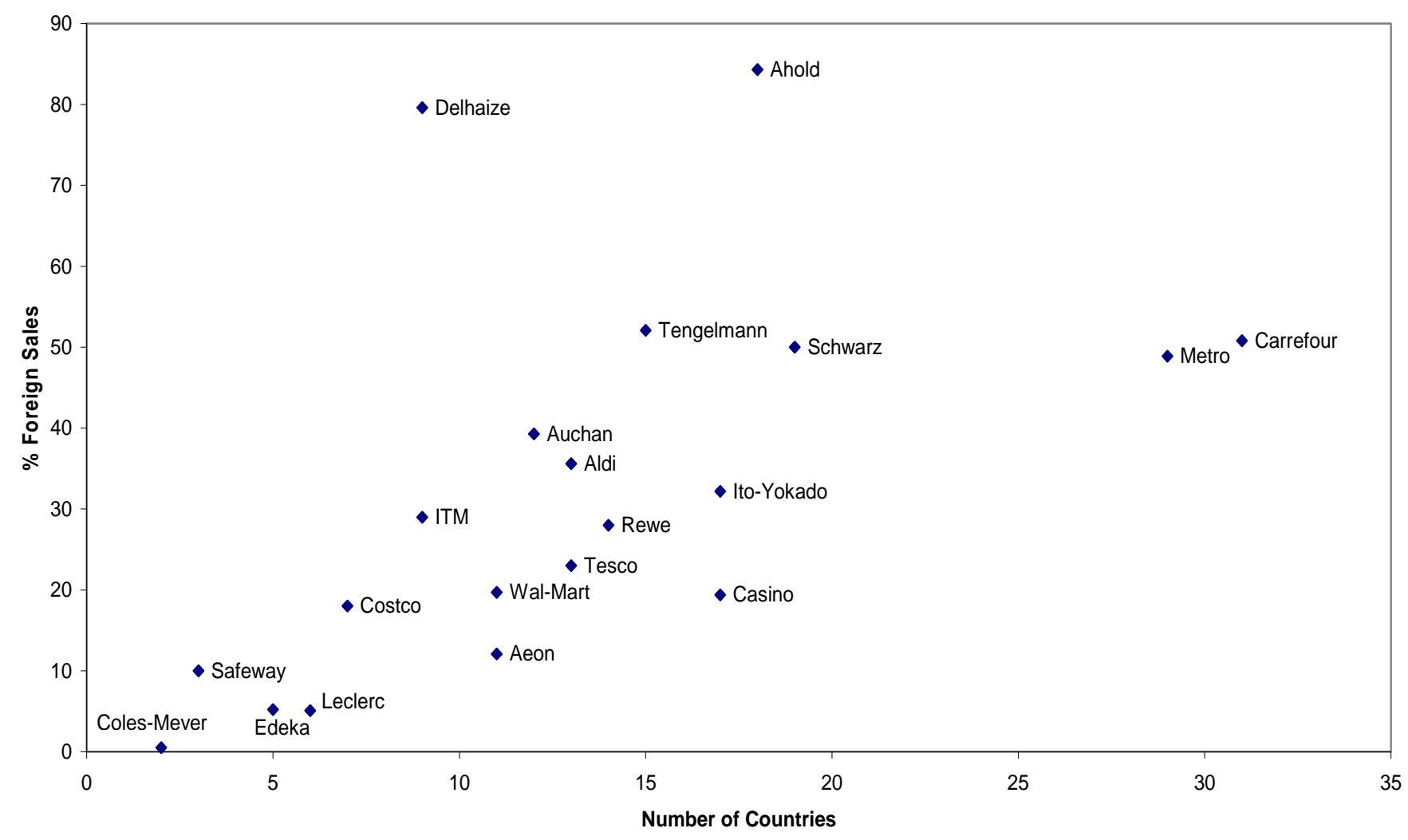

Source: Retail Forward (2005) 